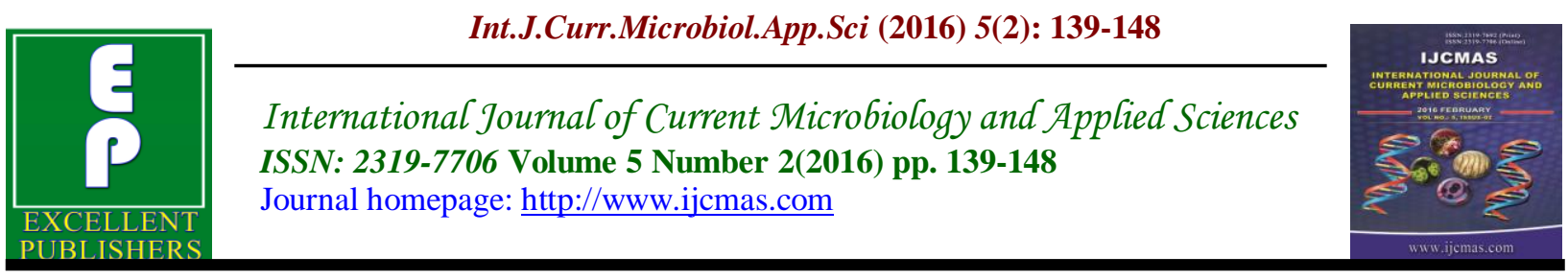

Original Research Article

doi: http://dx.doi.org/10.20546/ijcmas.2016.502.016

\title{
Role of Pseudomonas stutzeri MTCC101 in Cadmium Bioremediation
}

\begin{abstract}
Debarati Halder and Malini Basu*
Department of Microbiology, Barrackpore Rastraguru Surendranath College, 6

Riverside Road and 85 Middle Road, Barrackpore, Kolkata-700 120, India

*Corresponding author

A B S T R A C T

Keywords

Cadmium resistance, Pseudomonas stutzeri, Biosorption, EPS, SEMEDAX.

Article Info

Accepted: 15 January 2016 Available Online: 10, February 2016

Gram-negative bacteria like Pseudomonas are well reported to play a significant role in detoxification of various heavy metals like cadmium. The possible way to remove cadmium from the environment is to immobilize the metal within the system. Pseudomonas stutzeri MTCC 101, a highly cadmium tolerant strain harbors a mega plasmid $(\sim 15 \mathrm{~kb})$ which is likely responsible for such metal tolerance. However MTCC 101 showed conspicuous morphological abnormalities as revealed by SEM-EDX analysis. Focus was given to determine the biosorption potential of the organism. Optimization of biosorption potential of MTCC 101 showed that the mid log phase cells could accumulate maximum $\mathrm{Cd}^{2+}$ at neutral $\mathrm{pH}$ when cell-metal mixtures were incubated for about $30 \mathrm{hr}$ at $37^{\circ} \mathrm{C}$. MTCC 101 produces profuse EPS under metal stress which is likely to contribute to biosorption potential of the organism. Hence, the metal sorption potential of $P$. stutzeri could be effectively utilized in the bioremediation of cadmium.
\end{abstract}

\section{Introduction}

Cadmium is a naturally occurring element. Now a days this soft, silver-white metal used as an electrode component in alkaline batteries and also used in pigments, coatings, platings, stabilization of plastic (Fernando et al. 2013). It binds to thiol group (Edwards et al. 2013) resulting in protein denaturation; interacts with calcium and zinc metabolism affecting the skeletal system. Bioremediation processes are very attractive in comparison to physicochemical methods such as electrochemical treatment, ion exchange, precipitation, and reverse osmosis because they can have lower cost and higher efficiency at low metal concentrations (Gadd 1993; Chatterjee et al. 2012). Such processes are of industrial interest, since the removal of potentially hazardous heavy metal from industrial effluents by microbial biomass can lead to detoxification and also to recovery of valuable elements (Brierley et al. 1985). Microorganisms are efficient in doing both the biotransformation and could adsorb cadmium on their cell surface 
(Watcharamusika et al. 2008; Deb et al. 2013). Among them Gram negative soil bacteria Pseudomonas has widely been studied for their well adapted metal resistance properties (Singh et al. 2010; Deb et al. 2013). In this work, attempts have been made to elucidate the cadmium resistance potential of Pseudomonas stutzeri (MTCC101) and determine the optimal biosorption capacity of the organism.

\section{Materials and Methods}

\section{Bacterial Strains}

The strains of bacteria used in our study were obtained from Microbial Type Culture Collection (MTCC), IMTECH, Chandigargh, India. The strains are: a) Pseudomonas stutzeri (MTCC101) b) E.coli (MTCC390), a plasmid less strain.

\section{Chemicals}

Luria Bertani broth, Luria Bertani agar, Cadmium chloride dried (anhydrous), Tris base, EDTA $\mathrm{Na}_{2}$ salt, $\mathrm{NaOH}$, Dextrose, $10 \%$ SDS, Potassium acetate, Agarose low EEO, Ethanol, Phenol, Chloroform, Isopropanol, RNase A, Lysozyme, Loading dye 5X, EtBr, $\mathrm{HCL}$, Glacial acetic acid, $\mathrm{CaCl}_{2}, 2 \% \mathrm{HNO}_{3}$, $\mathrm{H} 2 \mathrm{SO}_{4}$. All chemicals used were of analytical grade and purchased from Himedia, SRL, and Merck.

\section{Growth of Pseudomonas stutzeri (MTCC 101)}

Degree of resistance of MTCC 101 was evaluated in LB containing 100 to $800 \mu \mathrm{g} / \mathrm{ml}$ cadmium. Growth of MTCC 101 in LB was determined by measuring the optical density at $540 \mathrm{~nm}$ using the un-inoculated broth as blank. Relative growth of MTCC 101 was expressed as the percentage of those obtained in untreated control which was taken as $100 \%$.

Isolation of Plasmid from MTCC 101 for Transformation of Plasmidless $E$. coli МTCC 390

Plasmid was isolated from MTCC 101 by alkaline lysis method; the concentration of plasmid determined by UV-VIS Spectrophotometer $118 \quad$ (Systronics); electrophoresed in $0.8-1 \%$ agarose, visualized under UV Transilluminator with filter $(312 \mathrm{~nm})$. A plasmidless strain E. coli MTCC 390 was transformed by $\mathrm{CaCl}_{2}$ method (Malik and Jaiswal 2000) and transformants thus obtained were screened for their cadmium tolerance in LA supplemented with $100 \& 200 \mu \mathrm{g} / \mathrm{ml}$ of cadmium.

\section{Growth Acclamatization}

Transformed MTCC 390 cells were initially grown in Luria Broth supplemented with $100 \mu \mathrm{g} / \mathrm{ml} \mathrm{Cd}+$ overnight at $37^{\circ} \mathrm{C}$, shaking and OD at 540nm determined. Cells were then passaged from the overnight grown culture into LB supplemented with higher $\mathrm{Cd}^{2+}$ concentration upto $700 \mu \mathrm{g} / \mathrm{ml}$ to compare the tolerance level of the transformed cells to that of the parent culture.

\section{Determination of Highest Sublethal Concentration of Curing Agents}

Acridine orange, Sodium dodecyl sulphate (SDS), elevated temperature, mitomycin-C were used to cure the plasmid. Sublethal doses of these agents were determined to select optimum conditions for curing. The growth of strain MTCC 101 was tested in Luria broth, separately containing acridine orange $(5,10,20,40 \mu \mathrm{g} / \mathrm{ml}), \operatorname{SDS}(2,4,6,8$ $\& 10 \%)$, elevated temperature $\left(25^{\circ} \mathrm{C}, 30^{\circ} \mathrm{C}\right.$, $\left.37^{\circ} \mathrm{C}, 40^{\circ} \mathrm{C}, 45^{\circ} \mathrm{C}, 50^{\circ} \mathrm{C}\right)$, mitomycin- $\mathrm{C}(5$, 
$10,15,20,25,50,75,100 \mu \mathrm{g} / \mathrm{ml})$. For this purpose sterilized solutions of curing agents were added to luria broth $(5 \mathrm{ml})$. Freshly grown cultures were used to inoculate luria broth supplemented with the curing agents. MTCC 101 inoculated luria broth without curing agent served as control. The tubes were incubated in a shaker at $37^{\circ} \mathrm{C}$ and 120 rpm for 24-48 hrs. The cells growing in presence of different concentration of curing agents were enumerated on luria agar plates.

\section{Curing of Plasmid}

Plasmid curing trials were carried out by using acridine orange, mitomycinC, SDS, elevated temperature at their highest sublethal doses i.e $40 \mu \mathrm{g} / \mathrm{ml}, 100 \mu \mathrm{g} / \mathrm{ml}, 10 \%$, $50^{\circ} \mathrm{C}$ respectively, in luria broth . Luria agar supplemented with cadmium chloride $(100 \mu \mathrm{g} / \mathrm{ml} \& 200 \mu \mathrm{g} / \mathrm{ml})$ and ampicillin (10mcg) impregnated disc were used as markers in the curing experiment. Viability of the cells was confirmed on luria agar plates and cured cells were selected by replica plating. Loss of plasmid from the cured cells was further confirmed.

\section{Biosorption of Cadmium by Pseudomonas stutzeri (MTCC 101)}

Luria broth supplemented with varying concentration of $\mathrm{Cd}^{2+}(100,200$ and $400 \mu \mathrm{g} / \mathrm{ml}$ ) was inoculated with MTCC 101 incubated for $24 \mathrm{~h}$ at $37^{\circ} \mathrm{C}$, shaking. The culture was then centrifuged at $8000 \mathrm{rpm}$ for $10 \mathrm{~min}$ at room temperature. The oven-dried $\left(+/-80^{\circ} \mathrm{C}\right)$ cell pellet was subjected to acid digestion using standard method (Basu and Paul 2008). Amount of cadmium (\%) present in the cell-pellet \& culture supernatant was estimated by AAS (Agilent spectra). Optimization of biosorption potential of the MTCC 101 was hence determined in relation to cell age, metal concentration, period of incubation, $\mathrm{pH}$ and temperature by incubating the cell-metal mixture under varying condition.

\section{EPS Production and its Cd Biosorption Potential}

Extracellular polymeric substances (EPS) produced by MTCC 101 was extracted from mid log phase culture (10hr old) using standard method (Chatterjee et al. 2012). Briefly cells grown in presence of varying concentration of $\mathrm{Cd}(100-800 \mu \mathrm{g} / \mathrm{ml})$ and without the salt (as control) were centrifuged at $7000 \mathrm{rpm}$ for $10 \mathrm{~min}$; EPS was extracted from the pellets and the amount of polysaccharide, protein, DNA, RNA were measured by standard methods. Additionally the extracted EPS was incubated in varying cadmium concentration $(200,400,600,800$, $1000 \mu \mathrm{g} / \mathrm{ml}$ ) at $37^{\circ} \mathrm{C}, \mathrm{pH} 7$ for $30 \mathrm{hr}$ to determine the metal accumulation by AAS.

\section{SEM-EDX Analysis for Cadmium Accumulation by MTCC 101}

Cells obtained from $10 \mathrm{ml}$ overnight grown broth cultures of MTCC 101 in LB containing $\mathrm{Cd}(0,400$ and $800 \mu \mathrm{g} / \mathrm{ml})$ were subjected to SEM (FEI QUANTA 200), EDX (ED3 Hindhivac direct drive rotary vacuum pump) analysis after requisite processing for visualization of metal biosorption (Jaysankar et al. 2008). Also interference of other heavy metals $(\mathrm{Mn}, \mathrm{Ni}$, $\mathrm{Co}, \mathrm{Cu}, \mathrm{Cr}, \mathrm{Zn}, \mathrm{Hg}$ ) along with cadmium on growth and surface accumulation on bacterial cells were also studied.

\section{Results and Discussion}

\section{Relative Growth of MTCC 101}

The relative growth of MTCC 101 revealed that after $24 \mathrm{hrs}$ of incubation there was drastic reduction in growth with increased cadmium concentration (Table 1). It 
indicates that apparently the organism was not a very $\mathrm{Cd}$ tolerant strain. However on prolonged incubation for 48-72 hour the organism got acclimatized to the metal stress and was able to tolerate and grow showing more than $50 \%$ relative growth at the highest concentration of $\mathrm{Cd}(800 \mu \mathrm{g} / \mathrm{ml})$.

\section{Isolation of Plasmid from MTCC 101 for Transformation of Plasmidless $E$. coli MTCC 390 and Growth Acclamatization}

Transformed colonies were observed on $\mathrm{Cd}$ (upto $150 \mu \mathrm{g} / \mathrm{ml}$ ) incorporated LA plates. The transformation efficiency of MTCC 390 was $300 \mathrm{cfu} / \mathrm{ng}$ of DNA. MTCC 101 harbours a megaplasmid $(\sim 15 \mathrm{~kb})$ which upon transformation into MTCC 390 (originally plasmidless strain) yeilded transformants having comparable cadmium tolerance (Fig. 1 \& 2). The bacterial resistance to antibiotics and heavy metals are the common phenotypic characters, which are often plasmid encoded (Trevors 1985).

\section{Curing of Megaplasmid}

Acridine orange, SDS, elevated temperature, mitomycinC were separately tried for curing of megaplasmid. Highest sublethal dose of the curing agent was determined. Among them mitomycin $\mathrm{C}$ alone appeared to be effective in curing the plasmid. Cells were not viable at above $50 \mu \mathrm{g} / \mathrm{ml}$ mitomycin $\mathrm{C}$ concentration. So, $50 \mu \mathrm{g} / \mathrm{ml}$ was the highest sublethal concentration of mitomycin $\mathrm{C}$ used. MitomycinC treated $(50 \mu \mathrm{g} / \mathrm{ml})$ cells showed loss of cadmium as well as ampicillin resistance property whereas untreated cells were resistant to cadmium chloride $(100$ to $800 \mu \mathrm{g} / \mathrm{ml})$ as well as ampicillin (10mcg) (Fig. 3 a \& b) indicating that the gene $(s)$ conferring cadmium and antibiotic resistance is plasmid mediated. This finding corroborates with Pseudomonas strain WP19 which was resistant to $\mathrm{Cu}, \mathrm{Ni}$, $\mathrm{Cd}$ and $\mathrm{Cr}$ and having plasmids of 20.8,
19.6, 8.0 and $4.7 \mathrm{~kb}$ approximately (Malik and Jaiswal 2000, Ünaldi et al. 2003)

\section{Biosorption of Cadmium by Pseudomonas stutzeri (MTCC 101)}

Microorganisms are often known to produce extracellular polymeric substance (EPS) localized at or outside the cell surface $\&$ are composed of high molecular weight organic macromolecules such as polysaccharides, proteins, nucleic acids, and phospholipids (Wingender et al. 1999) From the Atomic Absorption Spectroscopy studies it is evident that MTCC 101 when grown in presence of increasing concentration of cadmium could accumulate the metal maximally upto a certain level $(400 \mu \mathrm{g} / \mathrm{ml})$ beyond which it could not accumulate even on increasing the incubation period (Fig. 4). At $400 \mu \mathrm{g} / \mathrm{ml} \mathrm{Cd}^{2+}$, the amount of cadmium in the cell pellet versus supernatant was around $50-50 \%$ and this was true for $24 \mathrm{~h}$ incubation. Hence all further studies were done using $400 \mu \mathrm{g} / \mathrm{ml}$. Cells at different growth phases were harvested \& cell-metal mixture were incubated for varying time at varying $\mathrm{pH}$. It was found that mid log phase cells (Fig. 5a) could accumulate maximum $\mathrm{Cd}^{2+}$ at neutral pH (Fig. 5c) and $37^{\circ} \mathrm{C}$ (Fig. $5 \mathrm{~d})$ when the mixtures were incubated for about 30h (Fig. 5b).

Such biosorption property of the organism may be attributed partially via the extracellular polymeric substance (EPS) production in addition to the cell membrane associated metal accumulation as reported earlier (Deb et al. 2013). Metal resistant bacterial strains have been found to produce high amount of exopolymer during growth in presence of heavy metals. As shown in Fig. 5 MTCC 101 was capable to produce wide range of polysaccharide $\&$ protein with increasing concentration of cadmium (Fig. 6a). 
Table.1 Relative Growth of MTCC 101 in LB Supplemented with Varying Concentration of Cadmium ( 0 to $800 \mu \mathrm{g} / \mathrm{ml}$ ) for $24,48 \& 72$ Hours

\begin{tabular}{|c|c|c|c|}
\hline \multirow{2}{*}{$\begin{array}{l}\text { MTCC } 101 \text { grown in } \\
\text { LB supplemented with } \\
\text { cadmium }(\mu \mathrm{g} / \mathrm{ml})\end{array}$} & \multicolumn{3}{|c|}{ Relative growth (\%) } \\
\hline & 24 hour & 48 hour & 72 hour \\
\hline 1. 100 & 77.52 & 77.34 & 77.34 \\
\hline 2. 200 & 73.03 & 73.42 & 73.42 \\
\hline 3. 300 & 66.29 & 69.06 & 69.06 \\
\hline 4. 400 & 66.29 & 67.40 & 67.40 \\
\hline 5. 500 & 6.74 & 57.45 & 66.85 \\
\hline 6. 600 & 2.80 & 30.38 & 65.74 \\
\hline 7. 700 & 0.00 & 19.33 & 57.45 \\
\hline 8. 800 & 0.00 & 14.36 & 55.24 \\
\hline
\end{tabular}

All values represent the average of triplicates

Fig- 1

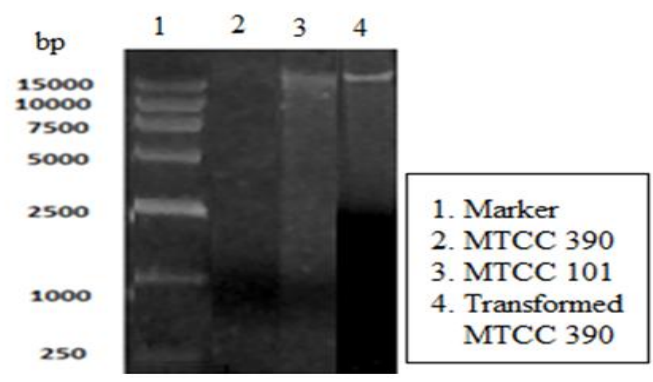

Fig- 3

(a)

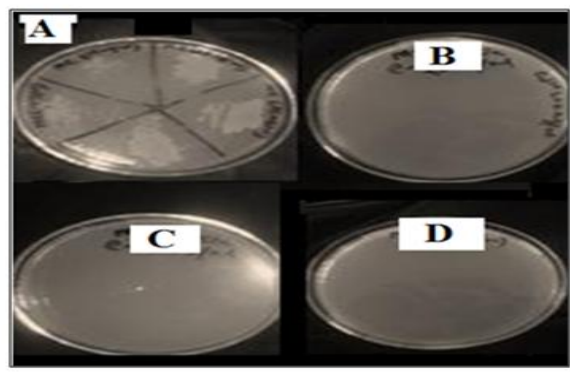

Fig.1 Detection of Plasmid in MTCC 101, MTCC 390 and Transformed MTCC 390; Fig.2 Comparison of Growth of MTCC 101 and Transformed MTCC 390 in Cd2+ Supplemented LB; Fig.3a Growth of P. stutzeri (MTCC 101) in absence (A) and presence (B, C, D) of Cd after plasmid curing with Mitomycin C (MMC): P. stutzeri after treatment with MMC was streaked on Luria agar (A), Luria agar supplemented with cadmium (B: MMC 50, C: MMC 75, D: MMC $100 \mu \mathrm{g} / \mathrm{ml})$. After curing bacteria showed reduced $(<100 \mu \mathrm{g} / \mathrm{ml})$ tolerance to the metal. (b) Variation in antibiotic sensitivity profile of $P$. stutzeri by treatment with Mitomycin C: $P$. stutzeri originally resistant to ampicillin (Octadiscs GI minus, Himedia) after mitomycin $\mathrm{C}$ treatment showed exhibited result;

Fig-2
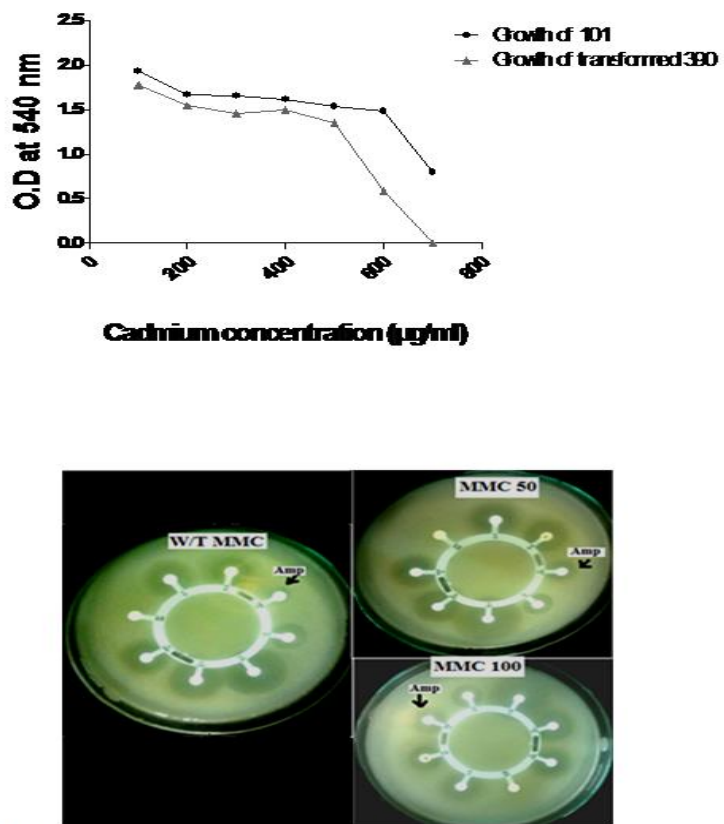

(b) 
Fig. 4

$\square 0 \mu \mathrm{g} / \mathrm{ml}, 100 \mu \mathrm{g} / \mathrm{ml}, \& 8200 \mu \mathrm{g} / \mathrm{ml}$,

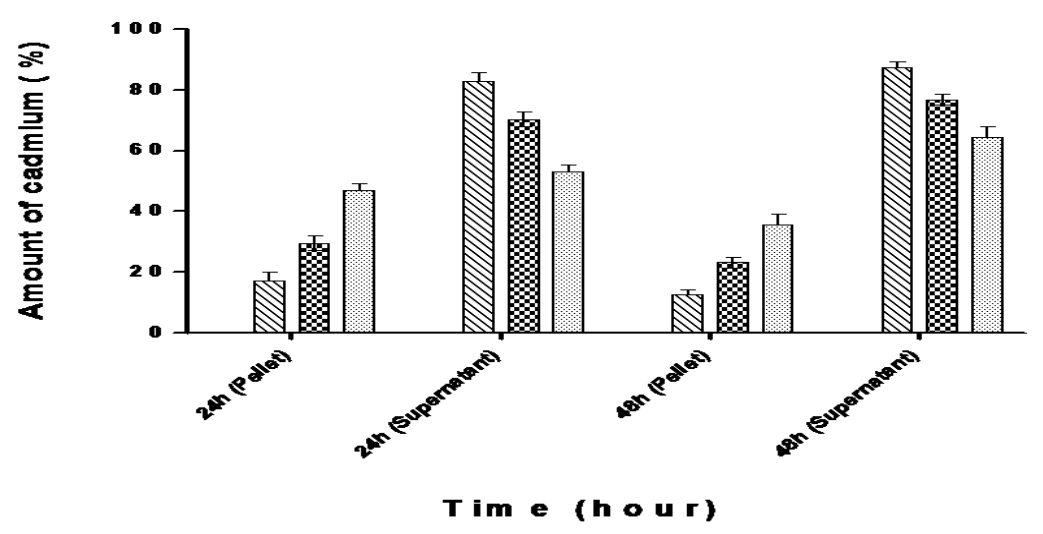

Fig.4 Accumulation of Cadmium by MTCC 101 Grown in Metal Supplemented LB

Fig. 5

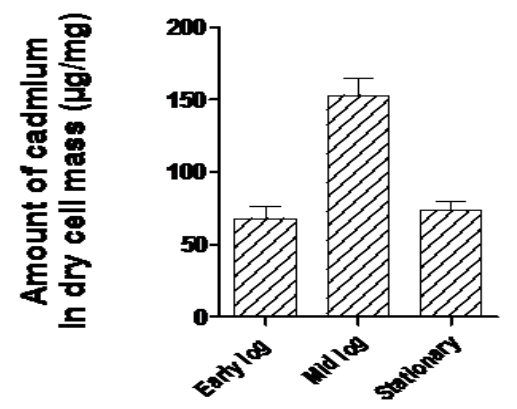

(a)

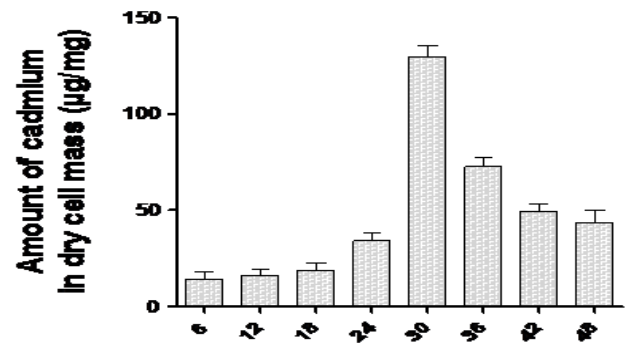

(b) Trme of incubation (hour)

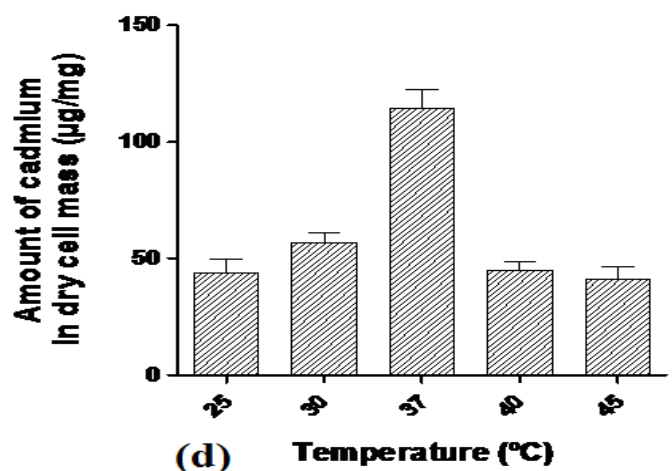

Fig.5 Optimization of Conditions for Cadmium Accumulation by MTCC 101. (a) Different Stage of culture (b) Varying Time (c) Varying $\mathrm{pH}$ (d) Varying Temperature 


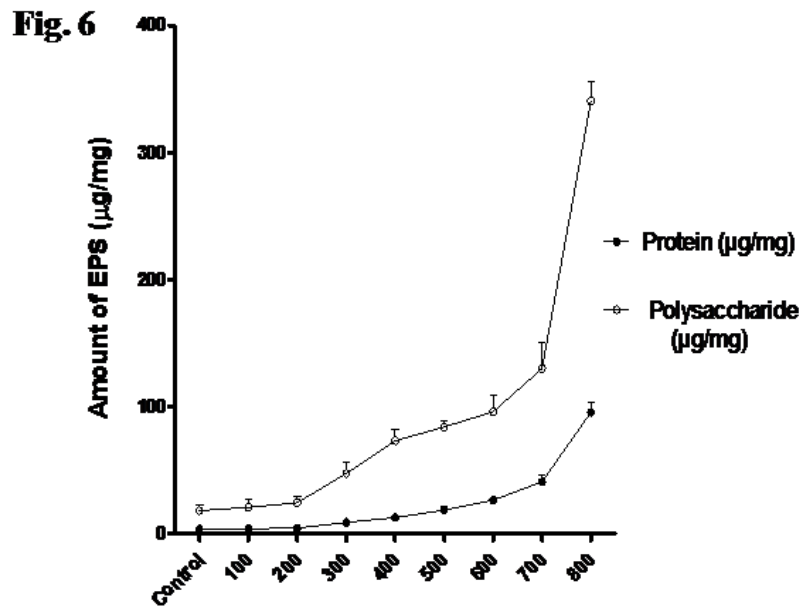

(a) Concentration of cadmium (ughm)

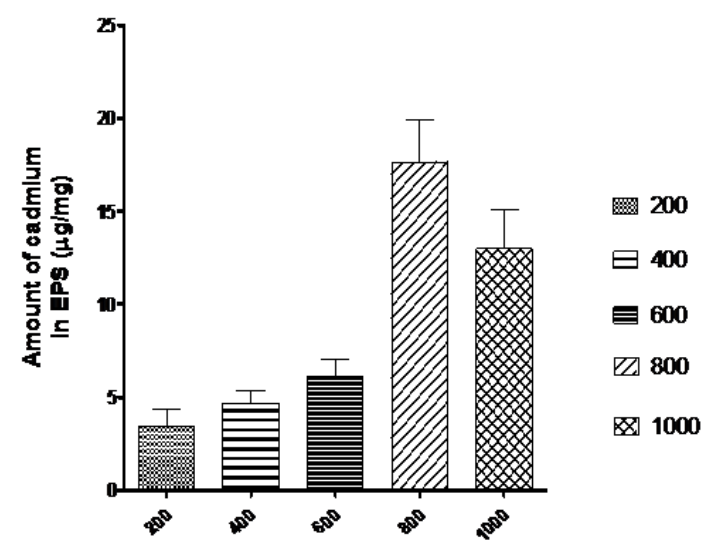

(b) Concertrafion of cadniem (ugim)

Fig.6 EPS Production and Biosorption of Cadmium by MTCC 101. (a) Cell Bound EPS in MTCC 101 under mMetal Stress (b) Biosorption of Cadmium by EPS Produced by MTCC 101
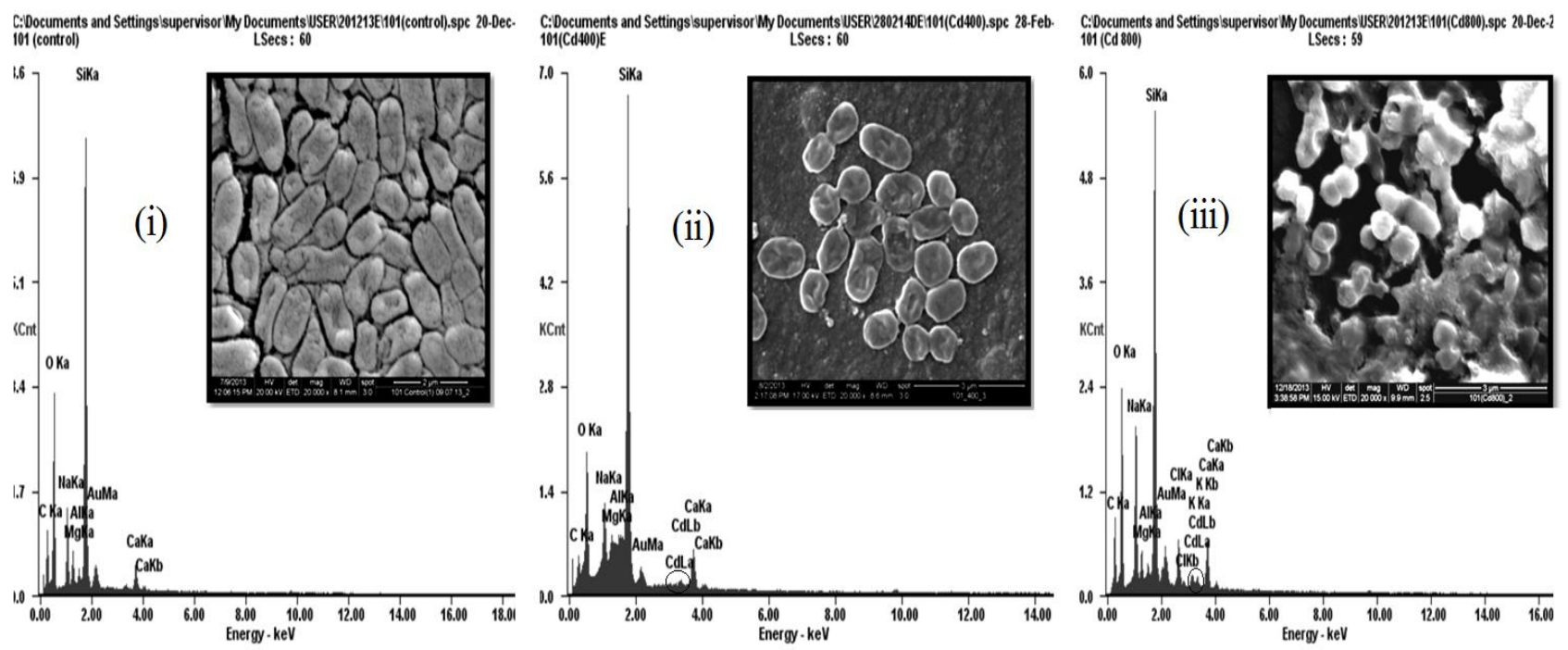

Fig.7 SEM EDAX ANALYSIS OF MTCC 101. Scanning electron microscopic view (20000X;

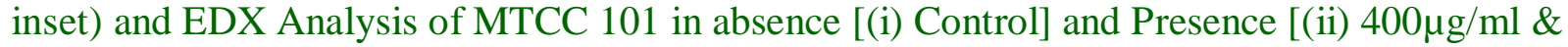

(iii) $800 \mu \mathrm{g} / \mathrm{ml}]$ of cadmium 

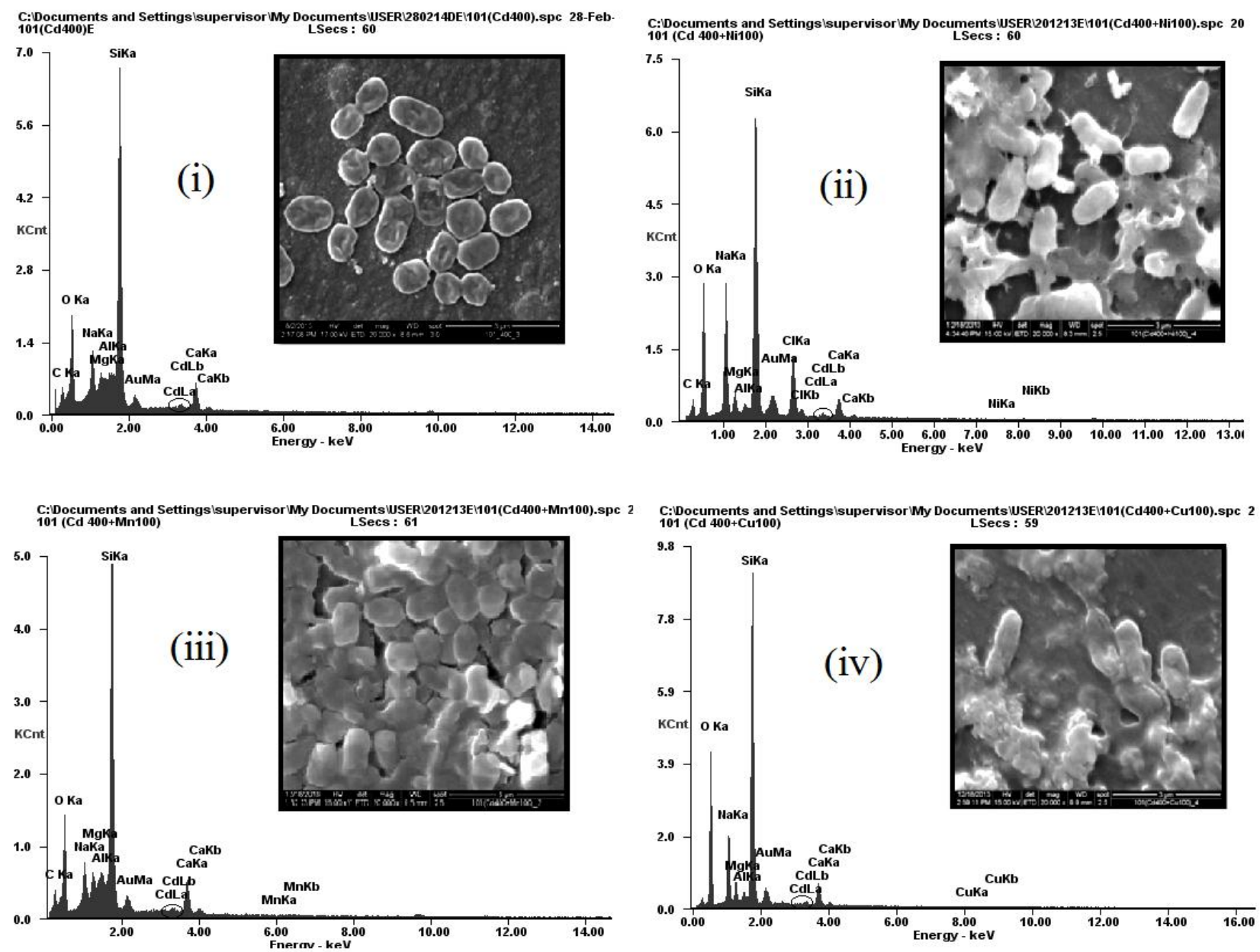

Fig.8 Interference of Ni, Co and Mn with Cadmium on MTCC 101. SEM analysis (20000X; inset) and EDX of MTCC 101 cells treated with cadmium alone [(i) 400 $\mu \mathrm{g} / \mathrm{ml}]$ and cadmium $(400 \mu \mathrm{g} / \mathrm{ml})$ with nickel [(ii) $100 \mu \mathrm{g} / \mathrm{ml}$ ], manganese [(iii) $100 \mu \mathrm{g} / \mathrm{ml}]$ and copper [(iv) $100 \mu \mathrm{g} / \mathrm{ml}]$

The EPS after extraction by standard method (Chatterjee et al. 2012) was incubated in cadmium chloride solution of varying concentration $(200-1000 \mu \mathrm{g} / \mathrm{ml})$. Pellets were washed twice in PBS, acid digested by standard method and subjected to AAS for analysis of cadmium. It was found that EPS alone could absorb maximum cadmium $(17 \mu \mathrm{g} / \mathrm{mg})$ when $800 \mu \mathrm{g} / \mathrm{ml}$ concentration of the metal was used (Fig. 6b) which was not comparable to that of previous reports (Kazy et al. 2002). Although metals get bound to the carbohydrate or protein moiety of the
EPS remaining outside the bacterial cell (Gutnick and Bach 2000), since the EPS produced by MTCC 101 upon analysis showed more of carbohydrate than protein content probably extracellular polymeric substances was not efficient in chelating.

\section{SEM-EDX Analysis for Cadmium Accumulation by MTCC 101}

Cadmium induced morphological variation \& surface accumulation of metal by MTCC 101 as is evidenced by SEM-EDX analysis. 
Unlike the cells grown in normal growth medium [Fig. 7(i)] presence of $\mathrm{Cd}$ at concentration $400 \mu \mathrm{g} / \mathrm{ml}$ [Fig. 7(ii)] \& $800 \mu \mathrm{g} / \mathrm{ml}$ [Fig. 7(iii)] in the medium resulted in abnormality in cell morphology suggesting toxic effect of the metal on the bacterial cells. In EDX spectrum Cd-L peak in the $\mathrm{Cd} 400 \mu \mathrm{g} / \mathrm{ml} \quad \& \quad 800 \mu \mathrm{g} / \mathrm{ml}$ respectively confirmed the presence of cadmium [Fig. 7(ii) and (iii)]. Additionally, peaks for other essential metals like O-K, $\mathrm{Na}-\mathrm{K}, \mathrm{Cl}-\mathrm{K}, \mathrm{Au}-\mathrm{M}, \mathrm{Mg}-\mathrm{K}$ were also found, which were already present in the culture media and were part of the cell surface components. Bacteria grown in medium without $\mathrm{Cd}$ showed no EDX signals [Fig. 7(i)].

Interference of other heavy metals like $\mathrm{Ni}$ [Fig. 8(ii)], Mn [Fig. 8(iii)], Co [Fig. 8(iv)], etc. with Cd affecting growth of MTCC 101 demonstrated varying results. In presence of $\mathrm{Mn}, \mathrm{Ni}$, Co $(100 \mu \mathrm{g} / \mathrm{ml})$ along with $\mathrm{Cd}$ $(400 \mu \mathrm{g} / \mathrm{ml}) \quad$ MTCC 101 although SEMEDAX data shows distorted cell morphology when grown in medium containing $\mathrm{Cd} \quad(400 \mu \mathrm{g} / \mathrm{ml})$ with $\mathrm{Ni}$ $(100 \mu \mathrm{g} / \mathrm{ml}) \quad \& \quad \mathrm{Cd} \quad 400 \mu \mathrm{g} / \mathrm{ml}$ with Co $100 \mu \mathrm{g} / \mathrm{ml}$. However in presence of cadmium $400 \mu \mathrm{g} / \mathrm{ml}$ with $\mathrm{Mn} 100 \mu \mathrm{g} / \mathrm{ml}$ the cells did not exhibit any notable distortion in morphology as compared to those when grown in $\mathrm{Cd}$ alone was similar to those reported by others as analysed by SEMEDX (Wong et al. 1978). Studies have shown that in Pseudomonas putida, presence of cadmium and nickel salts in growth medium resulted in reduction of cellular morphology to thin short rods. The resistance to cadmium and nickel may depend upon the membrane alteration which either prevent metal efflux or might produce efflux once the metal enters into the cell (Chakravarty et al. 2007).

In conclusion, P. stutzeri MTCC 101 was found to be a highly cadmium tolerant (plasmid borne strait) strain producing profuse EPS under metal stress which is likely to contribute to biosorption potential of the organism. Hence further elucidation of this tolerance potential by genomic and proteomic studies shall help one to dissect the bioremediation strategies.

\section{Acknowledgment}

Financial support from West Bengal DBT [BT (Estt)/RD-33/2014] and Barrackpore Rastraguru Surendranath College; Technical support from DR. M. K. Ghosh, IICB; DR. M. Pal, Bose Institute, DR. A. Kaviraj, Kalyani University are greatly acknowledged. We are also thankful to Prof. A. K. Paul, University of Calcutta for his constant support and guidance during the compilation of the work.

\section{References}

Basu, M, Paul, A.K. 2008. Influence of environmental factors on the uptake of chromium by Pseudomonas stutzeri TEM-317 isolated from tannery sludge. J Mycopathol Res. 46:289-295.

Brierley, C.L., Kelly, D.P., Seal, K.J., Best, D.J. 1985. In: I.J. Higgyns, DJ. Best, J. Jones (eds.), Biotechnology, Blackwell, Oxford. pp 163-212.

Chakravarty, R., Manna, S., Ghosh , A.K., Banerjee , P.C. 2007. Morphological changes in an Acidocella strain in response to heavy metal stress. Res $\mathbf{J}$ of Microbiol. 2:742-748.

Chatterjee, S., Mukherjee, A., Sarkar, A., Roy, P. 2012. Bioremediation of lead by lead-resistant microorganisms isolated from industrial sample. Adv in Bioscience and Biotechnol. 3:290-295.

Deb, S., Ahmed, S.F., Basu, M. 2013. Metal accumulation in cell wall: A possible mechanism of cadmium resistance by 
Pseudomonas stutzeri. Bull Environ Contam Toxicol. 90:323-328.

Edwards , C.D., Beatty, J.C., Loiselle, J.B.R., Vlassov, K.A., Lefebvre, D.D. 2013. Aerobic transformation of cadmium through metal sulfide biosynthesis in photosynthetic microorganisms. BMC Microbiol. 13:161.

Fernando, B.M., Luciane, P.C.M., Lisiane, H.F., Marco, A.M.O. 2013. Restrictions on the use cadmium coating in industries. ARPN J of Sci and Technol. 3:176-180.

Gadd, G.M., 1993. Microbial formation and transformation of organometallic and organometalloid compounds. FEMS Microbiol Rev. 11:297-316.

Gutnick, D.L., Bach, H. 2000. Engineering bacterial biopolymers for the biosorption of heavy metals; new products and novel formulations. Appl Microbiol and Biotechnol. 54:451460.

Jaysankar, D., Ramaiah, N., Vardanyan, L, 2008. Detoxification of toxic heavy metals by marine bacteria highly resistant to mercury. Marine Biotechnol. 10:471-477.

Kazy, S.K.,, Sar, P., Singh, S.P., Sen, A.K., D'Souza, S.F. 2002. Extracellular polysaccharides of a copper-sensitive and a copper resistant Pseudomonas aeruginosa strain: synthesis, chemical nature and copper binding. $\mathrm{W} \mathrm{J}$ of Microbiol and Biotechnol. 18:583588 .
Malik, A., Jaiswal, R. 2000. Metal resistance in Pseudomonas strains isolated from soil treated with industrial wastewater. W J Microbiol Biotechnol. 16:177182.

Maniatis, T., Fritsch, E.F., Sambrook, J. 1982. In: Molecular cloning: a laboratory manual, Cold Spring Harbor Laboratory, Cold Spring Harbor, N.Y.

Singh, V., Chauhan, P.K.., Kanta, R., Dhewa, T., Kumar, V. 2010 Isolation and characterization of Pseudomonas resistant to heavy metal contaminants. Int J Pharm Sci Rev Res. 3:164-167.

Trevors, J.T. 1985. Plasmid curing in bacteria. FEMS Microbiol Rev. 32:149-157.

Ünaldi, M.N., Korkmaz, H., Arikan, B., Coral, G. 2003. Plasmid-encoded heavy metal resistance in Pseudomonas sp. Bull Environ Contam Toxicol. 71:1145-1150.

Watcharamusika, A., Prapagdeea, B., Thavipokeb, P., Boontanon, N. 2008. The role of exopolymers in protection of Ralstonia sp., a cadmium-resistant bacterium, from cadmium toxicity Environment Asia. 2:37-42.

Wingender, J., Neu, T.R., Flemming, H.C. 1999. What are bacterial extracellular polymeric substances? In: Wingender J, Neu TR, Flemming HC (eds) Microbial Extracellular Polymeric Substances. Springer, Berlin, pp 1-20.

Wong, P.T.S., Chan, Y.K.., Luzon, P.L., 1978. Toxicity of a mixture of metals on freshwater algae. J. Fish Res Bd Can. 35: 479-481.

\section{How to cite this article:}

Debarati Halder and Malini Basu. 2016. Role of Pseudomonas stutzeri MTCC101 in Cadmium Bioremediation. Int.J.Curr.Microbiol.App.Sci. 5(2): 139-148. doi: http://dx.doi.org/10.20546/ijcmas.2016.502.016 